\title{
Developing nanotechnology in Latin America
}

\author{
Luciano Kay $\cdot$ Philip Shapira
}

Received: 22 April 2008/Accepted: 29 August 2008/Published online: 18 September 2008

(C) Springer Science+Business Media B.V. 2008

\begin{abstract}
This article investigates the development of nanotechnology in Latin America with a particular focus on Argentina, Brazil, Chile, and Uruguay. Based on data for nanotechnology research publications and patents and suggesting a framework for analyzing the development of R\&D networks, we identify three potential strategies of nanotechnology research collaboration. Then, we seek to identify the balance of emphasis upon each of the three strategies by mapping the current research profile of those four countries. In general, we find that they are implementing policies and programs to develop nanotechnologies but differ in their collaboration strategies, institutional involvement, and level of development. On the other hand, we find that they coincide in having a modest industry participation in research and a low level of commercialization of nanotechnologies.
\end{abstract}

L. Kay $(\bowtie)$

School of Public Policy,

Georgia Institute of Technology,

Atlanta, GA 30332-0345, USA

e-mail: luciano.kay@gatech.edu

P. Shapira

Manchester Institute of Innovation Research,

Manchester Business School,

University of Manchester,

Manchester M13 9PL, UK

e-mail: pshapira@mbs.ac.uk
Keywords Nanotechnology development .

Latin America - Research collaboration ·

Development · Strategies · International survey

\section{Introduction}

Through the manipulation of molecular-sized materials to create new products and processes with novel features due to their nanoscale properties, nanotechnology promises to be a leading driver of future technology-based business and economic growth around the world (Lux Research 2007). Advanced developed countries, including the US, Japan, and member states of the European Union, are investing billion of dollars annually in nanoscale research to build the scientific foundations for nanotechnology commercialization (Roco 2005; NSET 2007). China and Russia also are embarked upon major nanotechnology research programs (Applebaum et al. 2006; Kostoff et al. 2007; Zaitchik 2007). This presents both challenges and opportunities to other countries at medium levels of development. They have established science infrastructures and capabilities, but not of the scale and scope of the world's major R\&D performing nations. Yet, through targeted investments and strategic collaborations, intermediate countries could leverage their R\&D capabilities to absorb and advance new knowledge in 
nanotechnology research domains of relevance to their countries, be better placed to benefit from nanotechnology commercialization opportunities, and strengthen abilities to assess and manage potential nanotechnology risks.

This article investigates the development of nanotechnology in Latin America with a particular focus on Argentina, Brazil, Chile, and Uruguay. These countries form a contiguous block in the southern cone of Latin America and share various cultural and economic characteristics. All are middle-income countries (by the World Bank definition) with active research systems that receive from low-to-moderate levels of R\&D investment. There are also important differences: Argentina (2004 population: 38.4 million) and particularly Brazil (183.9 million people) are bigger and more industrialized countries, whereas Chile (16.1 million people) and Uruguay (3.4 million people) are smaller and depend more on their natural resources. However, they are similar in terms of per capita income and population-adjusted $R \& D$ inputs and outputs (Table 1).

To date, international studies of the development of nanotechnology and its potential impacts have focused mostly on the leading countries for nanotechnology R\&D and in so doing have highlighted the weaknesses of research on this topic for Latin America (Roco 2005; Besley et al. 2008). In this article, we undertake a fine-grain examination of the nanotechnology research and innovation landscape in selected Latin America countries. First, we review existing policies and programs to develop nanotechnology in Latin America and analyze institutions and areas of relative strength. We then put forward a framework for analyzing the development of R\&D networks. In particular, we identify three potential strategies of nanotechnology research collaboration: within-country collaborations, including those in subnational regional clusters; research collaborations among Latin American countries; and collaborations with nanotechnology researchers in leading countries outside Latin America. These strategies are not mutually exclusive, but each varies by scales of geographical and organizational proximity and in their likely research and innovation implications. With these strategic options in mind, we then analyze publication and patent data for Argentina, Brazil, Chile, and Uruguay to assess how nanotechnology $\mathrm{R} \& \mathrm{D}$ is developing in these countries and to examine the relative importance of the three strategies of collaboration. Finally, we discuss policy implications for these and other Latin American countries and offer some broader conclusions.

The empirical analyses presented in this article draw on global databases of nanotechnology publications and patents developed at the Georgia Institute of Technology, using the definition of nanotechnology and methods described in Porter et al. (2008). A two-stage modularized Boolean approach to defining nanotechnology combined with expert panel review was used to operationalize a definition of nanotechnology and develop publication and patent datasets for the 1990-2006 (mid-year) time period. This approach identified more than 400,000 records in the Web of Science's Science Citation Index (WOSSCI $)^{1}$ and nearly 54,000 abstracts of patents awarded in this same timeframe which were obtained from the MicroPatents database. ${ }^{2}$ A new dataset was created for the country group comprising Argentina, Brazil,

\footnotetext{
${ }^{1}$ It is recognized that SCI varies in strength by subject area (SCI is excellent for most life and physical sciences, but not quite as strong in chemical, medical, and engineering research.) Also, SCI does not cover all scientific journals, and in its coverage is weaker for scientific journals that publish in languages other than English. However, although SCI does index publication records in other languages, our data for the period 1990-2006 show that Argentina, Brazil, Chile, and Uruguay usually publish in English for nanotechnology research (more than $98 \%$ of the publications). In terms of local languages, Brazil published more than $1 \%$ of its SCI nanotechnology articles in Portuguese, Argentina more than $1 \%$ in Spanish, and Chile more than $3 \%$ in Spanish. All SCI nanotechnology research articles from Uruguay are written in English. On the other hand, there is evidence that developing countries are not well represented in international databases when it comes to analyzing total scientific output, because they often publish in national journals (Gaillard 1992). However, it is not clear how significant this is for the emerging field of nanotechnology. A search of SciELO (Scientific Electronic Library Online,) which specializes in providing online access to scientific journals in Latin America and the Caribbean, indicates that most of the domestic journals in Argentina, Brazil, and Chile that publish nanotechnology-relevant articles, including national and university journals in physics, chemistry, and materials science, are indexed in SCI (whether they publish in English or not) and many articles in these journals are published in English (Uruguay is not a member of SciELO). In short, while SCI is certainly not complete, it appears that it does capture much of the region's output of scientific articles in nanotechnology.

2 The patents database covers the USPTO, EPO, JPO, World Intellectual Property Office (WIPO), and patent offices of Germany, Great Britain, and France.
} 
Table 1 Economic, population, science and technology, and government nanotechnology R\&D for Argentina, Brazil, Chile, and Uruguay and selected reference countries (countries ranked by per capita income)

\begin{tabular}{|c|c|c|c|c|c|c|c|c|}
\hline Country & $\begin{array}{l}\text { GNI per } \\
\text { capita } \\
\text { US\$ PPP } \\
2006 \\
\text { (thousands) }^{\text {a,b }}\end{array}$ & $\begin{array}{l}\text { Income } \\
\text { group }^{c}\end{array}$ & $\begin{array}{l}\text { Population } \\
2006 \\
\left(_{\text {millions })^{a}}\right.\end{array}$ & $\begin{array}{l}\text { R\&D } \\
\text { spending } \\
(\% \text { GDP })^{\mathrm{d}, \mathrm{e}}\end{array}$ & $\begin{array}{l}\text { Researchers } \\
\text { in } R \& D^{\mathrm{e}, \mathrm{f}} \\
\text { (per million }\end{array}$ & $\begin{array}{l}\text { S\&E } \\
\text { articles } \\
2005^{\mathrm{g}} \\
\text { ulation) }\end{array}$ & $\begin{array}{l}\text { Patents } \\
2005^{\mathrm{e}, \mathrm{h}}\end{array}$ & $\begin{array}{l}\text { Government } \\
\text { nanotechnology } \\
\text { R\&D } \\
\text { (Estimated) } \\
\text { US\$ 2006 }\end{array}$ \\
\hline USA & 44.1 & HIC & 299.4 & 2.68 & 4,605 & 692.7 & 244 & 1,775 \\
\hline Japan & 32.8 & $\mathrm{HIC}$ & 127.8 & 3.15 & 5,287 & 434.0 & 857 & 975 \\
\hline Germany & 32.7 & HIC & 82.4 & 2.49 & 3,261 & 535.1 & 158 & 505 \\
\hline Spain & 28.2 & HIC & 44.1 & 1.11 & 2,195 & 422.5 & 53 & $50^{\mathrm{j}}$ \\
\hline Russia & 12.7 & UMC & 142.5 & 1.17 & 3,319 & 100.7 & 135 & 106 \\
\hline Mexico & 12.0 & UMC & 104.2 & 0.40 & 268 & 37.8 & 1 & $12^{\mathrm{k}}$ \\
\hline Argentina & 11.7 & UMC & 39.1 & 0.41 & 720 & 79.0 & 4 & $2^{1}$ \\
\hline Chile & 11.3 & UMC & 16.4 & 0.61 & 444 & 95.6 & 1 & $10^{\mathrm{m}}$ \\
\hline Uruguay & 9.9 & UMC & 3.3 & 0.26 & 366 & 58.3 & 1 & $-{ }^{\mathrm{n}}$ \\
\hline Brazil & 8.7 & UMC & 189.3 & 0.98 & 344 & 53.1 & 1 & $27-40^{\circ}$ \\
\hline China & 4.7 & LMC & $1,311.8$ & 1.44 & 708 & 31.9 & 16 & 220 \\
\hline India & 2.5 & LMC & $1,109.8$ & 0.85 & 119 & 13.3 & 1 & 106 \\
\hline
\end{tabular}

a World Bank, World Development Indicators

b Gross National Income per capita at Purchasing Power Parity (PPP). PPP exchange rates equalize purchasing power taking into account differences in costs between countries

c World Bank classification of countries by GNI per capita (2007): HIC, high income; UMC, upper middle income; LMC, lower middle income

${ }^{\mathrm{d}}$ Research and development spending as a percent of Gross Domestic Product

e United Nations Development Programme, Human Development Report, 2007/2008

f Latest data to 2005

g Science and engineering articles, from National Science Foundation, Science and Engineering Indicators, 2008, Appendix Table 534 , denominator is 2005 population

h Patents granted to residents

i 2006 Government funding on nanotechnology research (Lux Research 2007), except as noted. Conversions from $€$ to US\$ at European Central Bank exchange rate for relevant year

j 2006 estimate from data in Correia et al. (2007)

k 2004 data in European Commission (2005)

${ }^{1}$ Annualized 2005-2010 budget commitment of Fundación Argentina del Nanotecnología. Amount of additional public funds from other sources is unknown

m 2005 estimate (Foladori and Fuentes 2007)

${ }^{\mathrm{n}}$ In Uruguay, nanotechnology R\&D funding is provided at the university for a few projects, total is unavailable

${ }^{\circ}$ Estimated from data in Niosi and Reid (2007) and Malsch (2008b)

Chile, and Uruguay. ${ }^{3}$ This yielded a total of 7,309 publications and only 52 patents for the period 1990 2006. Since the total count of patents is very low, the analysis focuses mainly on publications with some additional comments about patenting activity.

\footnotetext{
3 This dataset comprises all records where at least one author affiliation is located in one of the four target countries.
}

\section{What is going on in nanotechnology in Latin America?}

Research publication performance

Several Latin American countries have set the development of nanotechnology as an objective to increase their competitiveness (Foladori 2006). However, scientific research has been concentrated primarily in 
Table 2 Nanotechnology publications for Latin America and selected reference countries, 1990$2006^{\mathrm{a}}$

a To first half of 2006

Source: Analysis of Georgia Tech global nanotechnology publication dataset. See Porter et al. (2008). World total for this time period $=450,465$

\begin{tabular}{lrll}
\hline Country & $\begin{array}{l}\text { Total nanotechnology } \\
\text { publications }\end{array}$ & $\begin{array}{l}\text { World Share (with } \\
\text { Latin American share) }\end{array}$ & $\begin{array}{l}\text { Nanotechnology publications } \\
\text { per million people 2005 }\end{array}$ \\
\hline Brazil & 5,456 & $1.2 \%(50.2 \%)$ & 4.7 \\
Mexico & 2,487 & $0.6 \%(22.9 \%)$ & 3.9 \\
Argentina & 1,318 & $0.3 \%(12.1 \%)$ & 4.6 \\
Chile & 481 & $0.1 \%(4.4 \%)$ & 4.5 \\
Cuba & 343 & $0.1 \%(3.2 \%)$ & 4.4 \\
Venezuela & 335 & $0.1 \%(3.1 \%)$ & 1.8 \\
Colombia & 301 & $0.1 \%(2.8 \%)$ & 1.0 \\
Uruguay & 54 & $0.0 \%(0.5 \%)$ & 2.6 \\
Peru & 45 & $0.0 \%(0.4 \%)$ & 0.3 \\
Costa Rica & 30 & $0.0 \%(0.3 \%)$ & 0.9 \\
Bolivia & 12 & $0.0 \%(0.1 \%)$ & 0.1 \\
Guadeloupe & 9 & $0.0 \%(0.1 \%)$ & 2.5 \\
Panama & 6 & $0.0 \%(1.1 \%)$ & 0.3 \\
Latin America & 10,887 & $2.4 \%(100.0 \%)$ & 3.1 \\
China & 51,620 & $11.5 \%$ & 7.5 \\
Germany & 41,793 & $9.3 \%$ & 59.6 \\
India & 9,399 & $2.1 \%$ & 1.6 \\
Japan & 47,894 & $10.6 \%$ & 48.5 \\
Spain & 9,675 & $2.1 \%$ & 35.3 \\
USA & 101,205 & $22.5 \%$ & 47.6 \\
\hline
\end{tabular}

three countries, Brazil, Mexico, and Argentina, which contributed about $85 \%$ of all nanotechnology publications from this continent during the period 19902006 (Table 2). ${ }^{4}$ In these countries, nanotechnology research activity in the field started in the early 1990s, but publication output did not begin to noticeably increase until the middle of that decade (Fig. 1)

At the aggregate level, Latin America's share of global nanotechnology publications grew in successive years between 1994 and 2002, rising to 3.6\% of the world's nanotechnology publication output in the latter year. Since 2002, although the actual number of publications has continued to increase, the continent's relative share of world output has declined. In 2005, Latin America contributed 3\% of the world's nanotechnology publications (Latin America's share

\footnotetext{
$\overline{4}$ At the aggregate level, Latin America contributed $2.6 \%$ of the world's total nanotechnology publications in that period. However, looking at its contribution per year, Latin America decreased from $3.6 \%$ of the total in 2002 to $2.5 \%$ in 2006. Generally speaking, this is the result of a relative increasing in research activity and publication in developed leading countries.
}

of world population was $8.6 \%$ in that year). ${ }^{5}$ In general terms, this relative decline reflects greater increases in research activity and publication in other leading countries. For example, between 2002 and 2005, annual nanotechnology publication rates increased by $57 \%$ for the US and $170 \%$ in China compared with 33\% for Latin America. By country, Brazil and Mexico have continued to expand absolute numbers of publications, while in Argentina, Chile, and Uruguay there has been a relative standstill in publication growth in recent years (Fig. 1). ${ }^{6}$ In terms

\footnotetext{
52005 population data from Population Division of the Department of Economic and Social Affairs of the United Nations Secretariat, World Population Prospects, 2007 Revision, available at http://esa.un.org/unup. The UN definition of Latin America includes Mexico and the Caribbean.

${ }^{6}$ Between 1994 and 2004, nanotechnology articles as a proportion of all published articles increased from 0.01 to 0.03 - which is about the same proportion as the US. However, Brazil's 2004 specialization in nanotechnology publications is noticeably lower than other fast emerging Asian economies such as China (0.10), South Korea (0.09), and Taiwan (0.07) which have more strongly emphasized nanotechnology as part of their national R\&D strategies (Data from Kostoff et al. 2006, Table 6).
} 


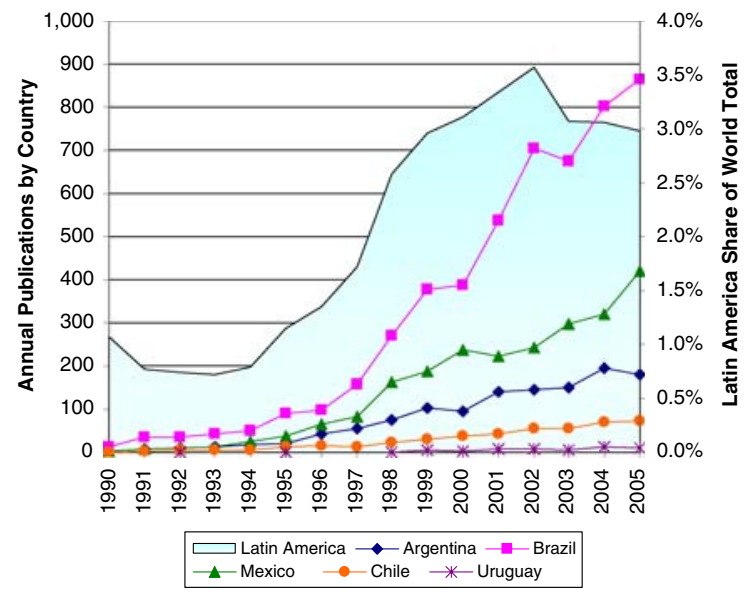

Fig. 1 Nanotechnology publications, annual, by leading Latin American countries and Latin American share of world total, 1990-2005. Source: Analysis of Georgia Tech global nanotechnology publications dataset

of research quality and impact, to the extent that this can be measured by citations recorded by SCI, the picture is also mixed. Nanotechnology articles authored in Argentina, Brazil, Chile, and Uruguay are less cited than the average for US authored articles, which is not unexpected (detailed in Table 4). While the impact trend is up slightly for Argentina and Chile when relative citations (as of mid-2006) for articles published in 2000 and 2004 are compared, it is down slightly for Brazil. Perhaps more significantly, while the relative impact trend is little changed in these Latin American countries, it has grown in other emerging economies, particularly in China and "Asian Tigers" (Singapore, Taiwan, and Korea.) For example, nanotechnology articles published in 2000 were relatively less well cited if authored in China than if authored in Brazil and similarly cited if authored in Argentina (as of mid-2006 compared with US articles published in the same year). However, for more recent articles published in 2004, Chineseauthored articles (although still less cited than US articles as of mid-2006) were attracting significantly more citations than Brazilian and Argentinean ones. ${ }^{7}$

\footnotetext{
7 Authors' analysis of Georgia Tech global nanotechnology publications dataset. For Chinese nanotechnology articles published in 2000 and 2004, SCI citations relative to US articles by mid-2006 were 0.38 and 0.47 , respectively. For Asian Tiger countries, the comparable averages were 0.44 and 0.51. See Table 3 in this article for Latin American comparisons.
}

$\mathrm{R} \& \mathrm{D}$ policies and programs

While research activity in nanotechnology began to pick up in Latin America in the 1990s, the implementation of dedicated nanotechnology-related policies and programs is a more recent phenomenon. For instance, nanotechnology policy in Brazil effectively started in 2001 with the creation of four institutional, multidisciplinary networks aimed at promoting research in the field. This initiative represented an important effort of the Conselho Nacional de Desenvolvimento Científico e Tecnológico $(\mathrm{CNPq})^{8}$ to develop nanotechnology in terms of human resources and funding. The Ministerio de Ciencia y Tecnología (MCT), the scientific community, and the private sector were the leaders in establishing the objectives of that initiative, including aims to balance regional development, integrate public and private research activities, and improve the technological level of Brazilian firms (Durán and De Azevedo 2002). According to Martins et al. (2007), during the period 2002-2005 those networks involved 300 researchers, 77 research and education institutions, and 13 companies, publishing more than a thousand research articles and obtaining more than 90 patents. Among the research areas that these networks sought to cover during this period were physics, chemistry, mathematics, medicine, biology, engineering, materials sciences, and computer sciences. The recent Rede BrasilNano program created ten new research networks to continue with that previous research, ${ }^{9}$ adding in this case a linking component between the program to develop nanotechnology and broader industry, technology, and trade policies (Invernizzi 2007). Furthermore, Brazil's new National Program of Nanotechnology seeks to reach $1 \%$ of the global markets for materials, products, and processes based on nanotechnology (Goncalves da Silva 2003).

Mexico is second in Latin America by published nanotechnology articles (and also by population). In 2004, there were eleven nanotechnology research

\footnotetext{
${ }^{8} \mathrm{CNPq}$ is a government agency whose mission is to promote and stimulate the scientific and technological development of the country and contribute to the formulation of national S\&T policy.

9 These new networks are still in an initial stage of implementation.
} 
groups at three universities and two research institutes, working primarily in new materials development (Malsch 2004); in 2007, an external European mission identified more than a dozen institutions with active nanotechnology research programs, again with a strong presence in nanomaterials (NanoforumEULA 2007). A few companies are also commercializing nanotechnology in Mexico, although academic-industry relationships are reported as weak (Malsch 2004). An important aspect for Mexico is the link maintained with the US in terms of cooperation for high-technology development which, jointly with the geographic proximity to that country, are hoped to offer Mexico an advantage for future commercialization of nanotechnology compared with other countries of Latin America. There are already some initiatives for supplying the semiconductor and other high-tech industries. For example, the project for the Silicon Border Development Science Park started in 2006 with the goal of becoming the first high-tech park in Latin America that is specialized at the nanoscale (Foladori and Zayago 2007). However, Mexico does not have a national program for developing these technologies. Indeed, until 2005 there was no federal program financing, organizing, or regulating nanotechnology (Foladori 2006). Additionally, Mexico consistently faces challenges of retaining its most highly talented researchers in the face of superior research conditions and salaries in the US. Some authors have also pointed out the lack of adequate intellectual property protection in Mexico as an obstacle for developing nanotechnology in the country (Kraul 2003; Malsch 2004).

Argentina, the third-ranked nanotechnology publisher in Latin America, has also implemented nanotechnology policy measures, including the creation of Fundación Argentina de Nanotecnología (FAN). ${ }^{10}$ FAN is a non-profit, private institution created by the Argentinean government in 2005 to lead the development of nanotechnology in the country. Its objectives include the development of human resources and infrastructure, the promotion of collaboration between national public and private institutions, the promotion of international collaborations, and the establishment of priority research areas (Andrini and Figueroa 2007). The advisory

$\overline{10}$ Argentinean Nanotechnology Foundation. council of FAN has membership from Argentina's most important organizations in nanotechnology including a national university, a state-owned company, and four key government S\&T and R\&D institutions. ${ }^{11}$ On the other hand, nanotechnology has been included as a strategic priority in the national S\&T agency's medium term plan and the national congress has put forward a 10-year nanotechnology plan (Sametband 2005). Several networks for nanoscience research have been established, including four networks sponsored by the National Agency for the Promotion of Science and Technology (ANPCYT) for molecular, supramolecular and interface nanoscience; nanostructure materials; bionanostructures; and the design and simulation of nano devices and prototypes (Malsch 2008a). An Interdisciplinary Centre for Nanoscience and Nanotechnology involving about 100 scientists from multiple locations with support from five companies has been formed (Malsch 2008a), and other private companies have demonstrated interest in developing and acquiring nanotechnology in the areas of chemistry, materials, biology, and textiles. However, this has not been accompanied by major increase in private research funding. In sum, according to Fernández and Schatzmann (2007), the nanotechnology community in Argentina comprises about 200 researchers in several government and university labs and institutions and about 20 private companies.

These three Latin American leaders are followed by Chile in terms of nanotechnology publications. Between 1999 and 2006, two broader programs to improve the Chilean S\&T system ${ }^{12}$ funded selected nanotechnology initiatives at six different universities $^{13}$ in the areas of physics, biology, and materials science. Despite this increased institutional

\footnotetext{
11 The institutions in the advisory council are: Universidad de Buenos Aires (UBA), Instituto Nacional de Tecnología Agropecuaria (INTA), Comisión Nacional de Actividades Espaciales (CONAE), INVAP SE, Consejo Nacional de Investigaciones Científicas y Técnicas (CONICET), and Instituto Nacional de Tecnología Industrial (INTI).

12 Chile recently implemented two main programs for improving R\&D: the Millennium Scientific Initiatives (a top-down policy recommended by the World Bank) and, more recently, the Bicentennial Program of Science and Technology.

13 They are: Universidad de Chile, Universidad de Santiago de Chile, Universidad Técnica Federico Santa María, Universidad Andrés Bello, Pontificia Universidad Católica de Chile, and Universidad de Concepción.
} 
involvement, Foladori and Fuentes (2007) point out that comparatively few researchers are working in nanotechnology in the areas of physics, chemistry, biology, and materials science. ${ }^{14}$ It is worth noting that recently Universidad de Santiago (one of the top Chilean universities working in nanotechnology) has announced joint research projects with universities in USA and Canada (Universia 2007).

The fifth-ranked Latin America country by absolute nanotechnology research output is Cuba (in relative terms, Cuba ranks second in Latin America by nanotechnology publications per million inhabitants). According to Cuba's Science and Technology Council (CCyT 2002), at least four institutions in this country have multiple years of research experience related to nanotechnology. ${ }^{15}$ Notwithstanding limited physical infrastructure, Cuba has produced a relatively large and well-trained group of scientists which are active in the development of nanotechnology, particularly nano-biotechnology (Foladori 2006). Available information on policy aims is limited to documents presented by the Cuban Academy of Sciences and the Ministry of Science, Technology, and Environment (CITMA) which point out the need for creating national capabilities in nanotechnology and establishing goals to work in related areas like mathematics, physics, chemistry, IT, and new materials (CCyT 2002).

Venezuela has published slightly less than Cuba. According to de la Vega et al. (2007), nanotechnology research in that country is clustered primarily in four institutions contributing $90 \%$ of the country's publications. ${ }^{16}$ These institutions also concentrate R\&D investment, scholarships, and sponsored projects. Those authors found some nanotechnology patenting activity in the country, corresponding generally to

\footnotetext{
${ }^{14}$ Foladori and Fuentes (2007) suggest that no more than 20 Chilean researchers are working in these disciplinary fields, excluding additional researchers that may be working in nanobiology.

15 They are: Universidad de la Habana (UH), Centro Nacional de Investigaciones Cientificas (CENIC), Instituto Superior Politecnico Jose Antonio Echeverria (ISPJAE), and Universidad Central de las Villas (UCLV).

16 They are: Universidad Central de Venezuela (UCV), Universidad Simón Bolívar (USB), Universidad de los Andes (ULA), Instituto Venezolano de Investigaciones Científicas (IVIC), and Instituto Tecnológico Venezolano del Petróleo (INTEVEP).
}

foreign inventors. However, to date, Venezuela lacks official policies or programs related to nanotechnology. More recent government initiatives are seeking to study the status of nanotechnology development in the country (de la Vega et al. 2007).

Colombia follows Venezuela in terms of publications. It established "advanced materials and nanotechnology" as a science and technology (S\&T) priority in 2004 (Foladori 2006). In 2005, a Nanotechnology Council was established in the country, under the Colombian section of the Institute of Electrical and Electronics Engineers (IEEE). This council was created to participate, jointly with universities, research centers, industry, and the government, in the development of nanotechnology in the country.

The rest of the Latin American countries contributed, individually, less than $1 \%$ of the continent's publications in the period 1990-2006 (Table 2). At the head of this group of following countries is Uruguay, which is undertaking nanotechnology research through the G-Nanotec-Uy (Uruguay Nanotechnology Group,) a group led by 15 researchers working at different labs in Universidad de la República (the main university in this country) ${ }^{17}$ and Instituto Clemente Estable. Their work is concentrated in areas of biology, physics, and materials science. According to an evaluation made by the same group, the further development of nanotechnology activities in Uruguay requires the definition of objectives and prioritization in the national S\&T strategy (Chiancone et al. 2007).

At least five other countries in Latin America are undertaking research in nanotechnology, namely Peru, Costa Rica, Bolivia, Guadeloupe, and Panama. These countries present different levels of initial development and interest in nanotechnology. For instance, in 2004, Costa Rica opened the National Laboratory for Nanotechnology, Microsensors and Advanced Materials (Lanotec.) which is the first center of this type in Central America. ${ }^{18}$ Other countries with very low activity in nanotechnology research, like Peru or Ecuador, have been working to

\footnotetext{
17 This university concentrates roughly $70 \%$ of the country's human resources in research and about one-third of its total research expenditure.

18 This is part of the National Center for High Technology (CeNAT). The initiative was funded by the Costa RicaUnited States of America Foundation for Cooperation, the Costa Rican Ministry of Science and Technology's incentive fund, and the Pro-Cenat Foundation (Vargas 2004).
} 
include nanotechnology among their national S\&T priorities. ${ }^{19}$

There is at least one joint initiative between the Latin American countries. The Centro Argentino Brasileño de Nanociencia y Nanotecnología (CABNN) is a virtual nanotechnology center bringing together research from groups working in Brazil and Argentina. It was created using the model of a previous cooperation experience in biotechnology, and its aim is using the science infrastructure of each country to develop joint projects, raise human resources capacity, create interchange grants for researchers, organize activities like forums and conferences, and increase interactions with industry (Almeida 2005; Diario LaU 2005). There are also multiple initiatives involving Latin American nanotechnology researchers with international projects sponsored by bilateral collaboration programs (particularly with the US, Germany, France, and the UK) and in some cases with European Commission support (Malsch 2008a, b). Generally, international support is a small although important complement to the collaborations that many Latin American research groups have established with colleagues in Europe, the US and elsewhere. These collaborations frequently draw on links established by Latin American researchers during graduate or postgraduate education and training abroad.

Although national agencies across Latin America indicate increased interest in promoting nanotechnology, public investment in nanotechnology $R \& D$ remains relatively modest (Table 1 ). Brazil—which leads in total government nanotechnology R\&D spending in Latin America-has a high-end estimated 2006 investment of about $\$ 0.21$ per capita (equivalent to $\$ 0.39$ when adjusted for Purchasing Power Parity or PPP). ${ }^{20}$ However, this is about three orders of

\footnotetext{
$\overline{19}$ For instance, the national S\&T agency of Ecuador (Secretaría Nacional de Ciencia y Tecnología-SENACYT) has included nanotechnology as a priority in its most recent policy document (Política Nacional de Ciencia, Tecnología e Innovación 20052010.) Also Peru established similar priorities in an S\&T plan for competitiveness and human development for 2006-2021 (Plan Nacional Estratégico de Ciencia, Tecnología e Innovación para la Competitividad y el Desarrollo Humano-PNCTI).

${ }^{20}$ Sources for government spending on nanotechnology R\&D as indicated in Table 1. For Latin American countries, estimates are based on available information and may be under-reported. Purchasing Power Parity (PPP) ratios were calculated based on World Bank, World Development Indicators, 2006, which is also the source of population estimates.
}

magnitude lower than the 2006 level of government nanotechnology R\&D investment found in the US (\$5.84 PPP per capita) although it is comparable to the estimated levels for China (\$0.39 PPP per capita) and greater than for India (\$0.29 PPP per capita.) Chile is relatively higher up on the scale of public nanotechnology $R \& D$ spending per capita, at $\$ 1.01$ PPP per capita, while Argentina is lower at \$0.12 PPP per capita. These comparisons of government nanotechnology $R \& D$ need to be put in the broader context of the generally low levels of R\&D spending as a proportion of the Gross Domestic Product found in Latin American countries (Table 1). Yet, despite limited overall levels of public nanotechnology R\&D funding, external expert missions do note the presence of capable laboratories and research groups in nanotechnology in Latin America, even though problems related to limited financial resources and links with industry are also observed (see, for example, mission reports on Argentina and Brazil in Malsch 2008a, b).

\section{Societal dimensions of nanotechnology}

Any assessment of strategies for developing nanotechnology in Latin American countries needs to take into account broader considerations and debates about the potential impacts (both positive and negative) of nanotechnology. Although nanotechnology is anticipated to lead to advances in many technological fields, multiple risks and societal concerns have also been identified, including health and environmental risks and needs for improved regulation (Glanzel et al. 2003; Roco 2003; Maynard 2006; Besley et al. 2008). This has given rise to uncertainty about not only the scale but also the distribution of nanotechnology's potential social, economic, health, and environmental impacts and risks (Cobb and Macoubrie 2004).

Reflecting these concerns and driven by desires to bolster the governance of nanotechnology development, initiatives have been sponsored in several advanced countries to analyze the broad range of impacts associated with nanotechnology and, in some cases, to engage stakeholders and the public, in dialogue and deliberation. How such efforts will constructively change the development of nanotechnology and its impacts remains to be seen (Bennett and Sarewitz 2006), but they are underway. For example, in the US, the consideration of "ethical, 
legal, environmental, and other appropriate societal concerns" in the development of nanotechnology is required by legislation, ${ }^{21}$ nanotechnology research centers are obliged to consider these issues, and new centers and projects have been sponsored to address these concerns (NSET 2004, 2005; Sarewitz and Guston 2004). Initiatives to consider the societal aspects of nanotechnology have also been launched in Europe and Japan (RAE 2004; Fogelberg and Sanden 2008; Ishizu et al. 2008).

In Latin America, the level of resources available for societal assessment is far lower than in developed countries. Yet, there is recognition that intermediate and developing countries could be vulnerable to risks associated with the application of nanotechnology, particularly given weaknesses in regulatory systems, yet may also lag behind developed economies in gaining economic benefits from this emerging technology (Invernizzi 2007; Invernizzi and Foladori 2005). For example, Invernizzi (2007) observes that nanotechnology in Brazil has been embraced and promoted by scientific elites as a mean for progress, efficiency, and competitiveness, but increasing social and economic inequalities in the country may actually prevent the technological benefits to be equally distributed. Indeed, in more general terms, Invernizzi and Foladori (2005) point out that the dominant socioeconomic structures in Latin American countries may hinder the deployment of nanotechnology applications that could provide benefits for the poorest groups. For example, these authors suggest that while quantum dot technologies have the potential to detect HIV/AIDS molecules at early onset, overstretched medical systems and an inability to afford expensive new treatments may limit use in developing countries. Moreover, they fear that even if nanotechnology in areas such as water filtration is applied in developing countries (including Latin America,) the poor majorities in these countries will not immediately benefit.

\section{Collaboration strategies for nanotechnology development in Latin American countries}

In seeking to develop nanotechnology in Latin America, both in terms of building research activities

21 Twenty-first Century Nanotechnology Research and Development Act, 2003, PL 108-153, 2(b)(10). and in influencing pathways for innovation and utilization, the level and character of research collaboration is an important factor. Since research resources are limited in all Latin American countries, collaboration can be helpful in leveraging available expertise and facilities, including providing access to equipment and instruments for researchers that lack such equipment in their home labs. Even more significantly, given the convergent nature of nanotechnology, research collaboration can be fundamental to undertaking interdisciplinary research, accessing up new sources of knowledge, and identifying and acting upon significant research problems (Heinze and Bauer 2007; Heinze et al. 2008). Research collaborations may also speed the transfer of knowledge for the deployment of nanotechnology, for example through collaboration between leading researchers in global centers and researchers in developing countries or, within a country, by teaming between academic and corporate researchers.

Although the possible permutations of research collaboration are many, we suggest that for Latin American countries there are three principal strategies for collaboration for developing nanotechnology: (1) within-country collaborations focusing on national priorities and targets; (2) supra-national regional collaborations with other countries in Latin America; and (3) international collaborations with researchers in countries outside Latin America, particularly in leading centers in advanced countries.

As previously noted, these strategies are not mutually exclusive, but each has different emphases with regard to geographical and organizational proximity and may have diverse implications in terms of research and application implications. For instance, a strategy to foster within-country collaborations will be based on indigenous capabilities and may reflect specific national goals for industry or sector targeting and meeting basic local demands or needs. There may also be longer-term goals of developing internal capabilities to develop products that can reach global markets through key export sectors. Emphasizing this strategy would require the involvement of key national groups $^{22}$ with, probably, government

\footnotetext{
22 Namely: main S\&T actors, universities, industry, financial community, and NGOs.
} 
coordination to establish national priorities and coordinate the national effort. ${ }^{23}$

The second strategy is one where research collaborations are developed across countries in Latin America. There are already existing regional alliances between major countries. For example, Argentina, Brazil, and Uruguay are permanent members of the regional trade agreement MERCOSUR, ${ }^{24}$ whereas Chile has an associate member status with this block. Conceivably, new research collaborations in nanotechnology may build upon such frameworks, as well as historical links, patterns of faculty and student exchange, and shared language (particularly for the Spanish-speaking countries). At present (and for the foreseeable future) such "Southern collaboration" linkages do not have anywhere near the funding levels or research infrastructures that, for example, are made available to supra-national collaboration through the European Union's Framework Programmes or Joint Research Centres. But interregional collaborations in Latin America could allow nanotechnology research to be undertaken with a more diverse set of actors.

The third strategy involves the development international research collaborations and alliances outside Latin America, particularly with leading international centers in the US, Europe, and other developed countries. Such linkages allow Latin American researchers opportunities both to tap into the frontiers of research and development and to catch-up with or replicate research done by technology leaders. At the same time, global collaborations may lead to technological developments that are more 3 with foreign rather than local interests, although in some cases developed countries maintain research programs which encourage their researchers to work with colleagues in developing countries on topics of particular relevance to the latter. Efforts toward international alliances are likely to be led by universities and research institutes (with perhaps the support

\footnotetext{
$\overline{23}$ For example, as implemented by the US federal government through its National Nanotechnology Initiative (NSET 2004) and in similar national initiatives in other advanced economies (Roco 2005).

24 The "Southern Common Market" (MERCOSUR) was created by Argentina, Brazil, Paraguay, and Uruguay in March 1991. The agreements of these countries include goals like gradual elimination of tariff barriers and harmonization of the macroeconomic policies.
}

of government departments, but not their management).

In this article, we use data on nanotechnology publication for Argentina, Brazil, Chile, and Uruguay to tease out clues as to the relative emphasis placed on each collaboration strategy by these Latin American countries. These countries not only represent a contiguous bloc in the southern cone of Latin America, but also offer contrasts in terms of nanotechnology R\&D standing. Brazil is the largest economy on the continent and is the Latin American leader in nanotechnology R\&D output. Argentina and Chile represent two medium-sized Latin American countries, with medium levels of nanotechnology R\&D output. Both these countries have active nanotechnology $\mathrm{R} \& \mathrm{D}$ policies and programs. Uruguay represents an example of a small Latin American country, with a modest nanotechnology R\&D effort.

For each of the four countries, we develop a series of variables, including ones related to co-authorship patterns, the organizational characteristics of first authors, institutional concentration, and research areas (see Table 3 for full variable list). We test for each of the three plausible collaboration strategies described above, hypothesizing that each strategy will be associated with different mixes of these variables. For example, a focus on national priorities is likely to be characterized by nanotechnology research led by single national institution or national collaborations and, if research is led by government labs, this would be also observed in first authorships. A focus on national priorities may also involve increasing research activity in industry (private or state-owned firms) and research areas aligned with key national industry sectors. On the other hand, if there is a focus on international alliances, we would expect to see this characterized by increasing co-authorship with international leading centers, institutional concentration, and prevailing academic first authorships. In this case, the research areas would likely be more aligned with leading centers' research and less related to national demands. Finally, a focus on Latin American regional collaboration would be indicated by co-authorships at the inter-regional level, led by either academic or government researchers.

In the next section, we proceed by mapping the current profile of nanotechnology research for the four Latin American countries that we have selected 
Table 3 Hypothesized strength of relationships between variables and main strategic components for elaborating nanotechnology development strategies in Latin America

Notes: In each cell is represented the extent to which the variable is positively related with each strategy, ranging from less related (Low) to more related (High)

\begin{tabular}{llll}
\hline Variables in dataset & \multicolumn{2}{l}{ Strategic components (Anticipated level) } \\
\cline { 2 - 4 } & $\begin{array}{l}\text { National } \\
\text { focus }\end{array}$ & $\begin{array}{l}\text { International } \\
\text { alliances }\end{array}$ & $\begin{array}{l}\text { Regional } \\
\text { collaborations }\end{array}$ \\
\hline Co-authorship intl. (all) & Low & Moderate & Low \\
Co-authorship intl. leading centers & Low & High & Low \\
Co-authorship regional neighbors & Moderate & Low & High \\
Single, natl. Institution & High & Moderate & Low \\
Natl. Collaborations & High & Moderate & Low \\
Institutional concentration & Low & High & Low \\
Acad. first author & Moderate & High & Moderate \\
Gov. first author & High & Low & Moderate \\
Research areas/natl. needs & High & Low & Moderate \\
alignment & & & \\
\hline
\end{tabular}

for detailed analysis to identify the balance of emphasis upon each of the three strategies. Following this, in the concluding section, we review the strategic research collaboration options and consider implications for nanotechnology R\&D policy.

\section{Country analysis: nanotechnology development in Argentina, Brazil, Chile, and Uruguay}

We analyze nanotechnology developments using data extracted from the Georgia Tech global nanotechnology publication and patent databases, as discussed in the introductory section. The data provide insights about how nanotechnology research is organized within the four selected countries (Argentina, Brazil, Chile, and Uruguay), how much research collaboration exists, and what are the components emphasized in the strategies of these countries.

Brazil is clearly the leader in nanotechnology research activity in this group, followed by Argentina, Chile, and Uruguay, in that order (Table 4). ${ }^{25}$ In Brazil, about 255 different institutions are undertaking nanotechnology research, with universities as the most active publishers. Government labs and industry publishing levels are surprisingly low in Brazil, Chile, and Uruguay, whereas in Argentina four

\footnotetext{
${ }^{25}$ Over the period 1990-2006, Brazil ranked 19th among all 101 countries globally with nanotechnology publications by cumulative total of nanotechnology publications. Comparative rankings for the other countries were: Argentina 34th, Chile 46th, and Uruguay 72nd. Source: Georgia Tech nanotechnology publication dataset (see Porter et al. 2008).
}

government labs are among the top 10 institutions with more than $40 \%$ of the national research (Table 5). It is worth noting that in Uruguay almost all research activity is concentrated in one university (Universidad La República.) Domestically undertaken research prevails in Brazil (comprising about twothirds of all published nanotechnology research) rather than collaboration with international leading centers $^{26}$ or regional co-authorships. This is in contrast to the case of Uruguay, where there are more international and, to less extent, regional collaborations ( $80 \%$ of the research is done with regional and international partners). Argentina and Chile present more average values: half of the nanotechnology publications of Argentina and 58\% of Chile's are coauthored with researchers from other countries (Tables 4, 6). This general pattern is not unexpected, in that the smaller a country's R\&D system, the more likely that its researchers will seek external collaborations. However, there are variations. For example, in its external collaborations, Chile is much more likely than Argentina to collaborate with other regional MERCOSUR neighbors.

As suggested by the dominant types of research institutions, authors from universities lead nanotechnology research in Brazil, Chile, and Uruguay, with a relatively low participation of government scientists in first authorships (Table 4). In the case of Argentina, government researchers have relatively more

\footnotetext{
${ }^{26}$ International collaborations with leading centers include collaborations with USA, France, Spain, Germany, Italy, England, Japan, Canada, Russia, and China.
} 
Table 4 Nanotechnology research profiles, Brazil, Argentina, Chile, Uruguay

\begin{tabular}{|c|c|c|c|c|}
\hline & Brazil & Argentina & Chile & Uruguay \\
\hline Organizations (number) & \multicolumn{4}{|c|}{ Nanotechnology research publishing organizations } \\
\hline Universities & 144 & 31 & 20 & 1 \\
\hline Gov Labs & 61 & 23 & 4 & 1 \\
\hline Industry & 30 & 6 & 3 & \\
\hline Other & 20 & 14 & 1 & \\
\hline Total & 255 & 74 & 29 & 2 \\
\hline Articles (published 1990-2006) ${ }^{\mathrm{a}}$ & \multicolumn{4}{|c|}{ Publications } \\
\hline Total & 5,456 & 1,318 & 481 & 54 \\
\hline Per 100,000 people & 2.97 & 3.27 & 2.95 & 1.56 \\
\hline Institutional concentration (Herfindahl) & 0.07 & 0.09 & 0.12 & 0.83 \\
\hline Relative to US articles (same publication year) & \multicolumn{4}{|c|}{ SCI Citations $2006^{\mathrm{a}}$} \\
\hline Published in 2000 & 0.37 & 0.40 & 0.26 & N/A \\
\hline Published in 2004 & 0.41 & 0.37 & 0.30 & 0.49 \\
\hline Organization (percent) ${ }^{\mathrm{b}}$ & \multicolumn{4}{|c|}{ First authorships } \\
\hline Academic & 74.8 & 54.1 & 69.2 & 48.1 \\
\hline Government & 5.7 & 21.5 & 0.0 & 1.9 \\
\hline Industry (private) & 0.2 & 0.1 & 0.0 & 0.0 \\
\hline Industry (public) & 0.8 & 0.0 & 0.2 & 0.0 \\
\hline Hospital & 0.1 & 0.4 & 0.0 & 0.0 \\
\hline Other (foundation, association) & 0.1 & 0.5 & 0.0 & 0.0 \\
\hline Collaboration type (percent) & \multicolumn{4}{|c|}{ Co-authorships } \\
\hline Co-authorship international (all) & 36.1 & 49.5 & 58.4 & 79.6 \\
\hline Co-authorship international leading centers ${ }^{\mathrm{c}}$ & 26.2 & 39.0 & 37.6 & 37.0 \\
\hline Co-authorship intra-MERCOSUR & 2.7 & 7.9 & 17.0 & 48.1 \\
\hline Single, national institution & 28.6 & 26.1 & 18.3 & 14.8 \\
\hline National collaboration $(2+$ local institutions only) & 35.3 & 24.4 & 23.3 & 5.6 \\
\hline Article subject categories (percent) ${ }^{\mathrm{d}}$ & \multicolumn{4}{|c|}{ Primary subject areas } \\
\hline Physics & 44.5 & 39.6 & 32.6 & 35.2 \\
\hline Chemistry & 22.3 & 31.1 & 31.6 & 24.1 \\
\hline Materials Science & 32.0 & 25.9 & 24.9 & 29.6 \\
\hline Biology & 4.9 & 6.2 & 10.0 & 7.4 \\
\hline Engineering & 7.1 & 6.0 & 3.7 & 11.1 \\
\hline Medicine & 5.7 & 4.1 & 9.8 & 5.6 \\
\hline Electronics & 4.5 & 3.0 & 4.0 & 7.4 \\
\hline Geology, Environmental, Energy & 1.4 & 2.8 & 3.5 & 11.1 \\
\hline Agriculture & 0.8 & 1.7 & 1.0 & 0.0 \\
\hline Mathematics, Computer Science & 0.6 & 0.5 & 0.2 & 0.0 \\
\hline
\end{tabular}

Source: Analysis of Georgia Tech global nanotechnology publication dataset

a To first half of 2006

b Totals do not add up to $100 \%$ because some publications have first authors from other countries (international or regional collaborations)

${ }^{\mathrm{c}}$ International collaborations with leading centers include collaborations with USA, France, Spain, Germany, Italy, England, Japan, Canada, Russia, and China

d Totals add up to more than $100 \%$ because some publications are categorized in more than one subject area 
leading participation as first authors. In addition, industry first authorship level is very low in all four countries. Although it is expected that industry will always be a much lower producer of research publications than the academic and government sectors, the levels found in our selected Latin American countries are particularly low. Industry first authorship of papers is close to zero in Uruguay and only a small fraction of $1 \%$ in Argentina and Chile. While nanotechnology research in Brazil involves more private and state-owned firms, they only account for roughly $1 \%$ of first authorships. By comparison, the equivalent industry authorship rate is $11 \%$ in the US and $2 \%$ in China, the latter being more comparable to Latin America (Shapira and Wang 2008). For Latin America, as in other emerging economies, the relatively small role of industry in nanotechnology $R \& D$ publication suggests weaknesses not only in research but also in absorptive capabilities to be able to industrially apply new nanotechnology innovations whether developed at home or elsewhere.

In spatial terms, nanotechnology research in our four focal countries is concentrated in an arc of cities mostly along the Atlantic and Pacific coasts. The top five leading regional nanotechnology research producing complexes (by articles published) are Sao Paulo, Campinas, Sao Carlos, and Rio de Janeiro in Brazil and Buenos Aires in Argentina. A second tier of regional complexes comprises Porto Alegre, Belo Horizonte Araraquara, Brasilia, Curitiba, Maringa, and Recife (Brazil), Santiago (Chile), and La Plata and San Carlos De Bariloche (Argentina) (Fig. 2).

In all four countries, there is a specialization in nanotechnology research in terms of both institutional participation and subject areas. Nanotechnology is mostly concentrated in three areas: physics, chemistry, and materials science, with only Uruguay showing relatively more publications in engineering and in geology, environmental, and energy (both areas with more than $11 \%$ of the country's publications) (Table 4). Nanotechnology research in this group of countries is also concentrated in relatively few institutions. Among the top 20 research institutions in the region there are 14 in Brazil, five in Argentina, and one from Chile. In Brazil, the majority of leading publishers are federal universities which contributed more than $80 \%$ of the region's publications (Table 5). Furthermore, there are two Brazilian universities (Universidade de São Paulo and Universidade Estadual de Campinas) which produce more than one-third of the nanotechnology research in our selected country group.

A network analysis further helps in understanding how research is done within these countries. We represented graphically the relationships between research institutions and obtained a measure of centrality for the top 50 institutions from Argentina, Brazil, Chile, and Uruguay (Fig. 3). As expected, most of the institutions in this network are from Brazil and few of them are from Argentina and Chile. Only one institution is from Uruguay. Generally speaking, the network shows the importance of collaborations within each country, particularly in Brazil. More interesting is that more publications do not make research institutions more central in this network, as shown by a measure of degree centrality. For example, Universidade Estadual de Campinas has about $40 \%$ less publications than Universidade de São Paulo (both from Brazil) and both have the same degree centrality (i.e., both are equally well connected to this regional network) (Table 7).

The analysis of patents would also help in understanding the development of nanotechnology commercialization efforts in these countries. However, the lack of patenting activity impedes detailed investigation. In our data, we find only 45 patent awards in the period 1990-2006 for Brazil, the most active country in our group. ${ }^{27}$ Other studies have suggested that nanotechnology patents granted by the Brazilian patent office are a little higher, but not by much. ${ }^{28}$ In general, patenting activity across all domains in Latin American countries is low compared to research publication output. For example, whereas there are about three science and engineering publications relative to every resident patent grant in the US and Germany and eight in Spain, the equivalent numbers for Argentina and Brazil are 20

\footnotetext{
27 Other research confirms the very limited patenting in the nanotechnology domain in Brazil. See, for example, Antunes (2004) who (with a narrower search term than we used) finds only two Brazilian nanotechnology patents out of more than 12,000 nanotechnology patents registered with the European Patent Office between 1994 and 2004.

28 According to Martins et al. (2007), the Ministerio de Ciencia y Tecnología of Brazil reported more than 90 patents as a result of the activities of the nanotechnology research networks between 2002 and 2005 .
} 
Fig. 2 Leading Nanotechnology Research City-Regions in Brazil, Argentina, Chile, and Uruguay. Source: Analysis of Georgia Tech global nanotechnology publication dataset. Only cities with 10 or more nanotechnology publications (1990-2006 mid) are shown

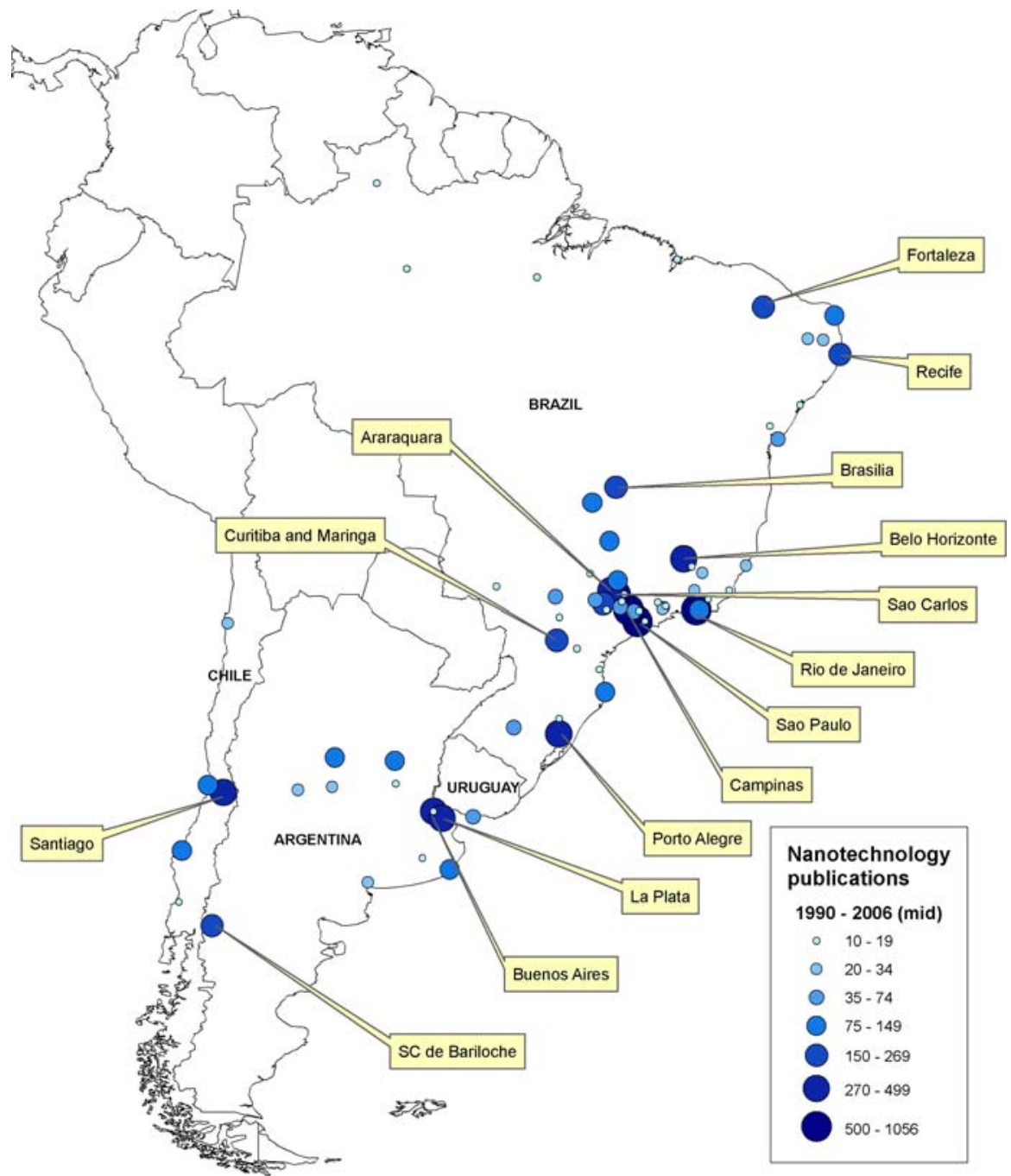

and 53, respectively (calculated from data in Table 1) Niosi and Reid (2007) note that public researchers and academics in Latin American often face constraints in undertaking private sector activities and incentives to encourage patenting are weak. This situation seems to be continuing for nanotechnology, foreshadowing issues in the industrial exploitation of nanotechnology research and knowledge in our four study countries as well as elsewhere in Latin America.

\section{Policy implications}

Our findings suggest policy issues and implications for our group of Latin American countries. For example, all four countries present some level of institutional concentration in their research. This is most pronounced in the case of Brazil, which seems to follow a strategy based on national targets rather than international collaboration, as suggested by the implementation of programs aimed at creating national research networks, like the Rede BrasilNano program. The institutional concentration of research is even greater in Uruguay (which is a much smaller country), but in this case it is consistent with its emphasis in regional collaborations and less developed S\&T system. Whether greater incentives for international collaboration in nanotechnology research in Latin America are appropriate is an issue that policymakers in these countries may wish to consider. 
Table 5 Most active institutions undertaking nanotechnology research by country (with number of identified nanotechnology publications and share of total publications for the four countries, 1990-2006) ${ }^{\mathrm{a}}$

\begin{tabular}{|c|c|c|c|c|c|c|c|}
\hline \multicolumn{2}{|l|}{ Brazil } & \multicolumn{2}{|l|}{ Argentina } & \multicolumn{2}{|l|}{ Chile } & \multicolumn{2}{|l|}{ Uruguay } \\
\hline $\begin{array}{l}\text { Universidade } \\
\text { de São } \\
\text { Paulo }\end{array}$ & $\begin{array}{l}1,424 \\
(19.5 \%)\end{array}$ & $\begin{array}{l}\text { Universidad } \\
\text { Nacional de La } \\
\text { Plata }\end{array}$ & $\begin{array}{l}291 \\
(4.0 \%)\end{array}$ & $\begin{array}{c}\text { Universidad } \\
\text { de Chile }\end{array}$ & $\begin{array}{l}123 \\
(1.7 \%)\end{array}$ & $\begin{array}{l}\text { Universidad La } \\
\text { República }\end{array}$ & $53(0.7 \%)$ \\
\hline $\begin{array}{l}\text { Universidade } \\
\text { Estadual de } \\
\text { Campinas }\end{array}$ & $\begin{array}{c}997 \\
(13.6 \%)\end{array}$ & $\begin{array}{l}\text { Universidad de } \\
\text { Buenos Aires }\end{array}$ & $\begin{array}{l}258 \\
(3.5 \%)\end{array}$ & $\begin{array}{l}\text { Universidad } \\
\text { de } \\
\text { Concepción }\end{array}$ & $\begin{array}{l}93 \\
(1.3 \%)\end{array}$ & $\begin{array}{l}\text { Instituto de } \\
\text { Investigaciones } \\
\text { Biológicas } \\
\text { Clemente } \\
\text { Estable- } \\
\text { IIBCE }\end{array}$ & $2(0.0 \%)$ \\
\hline $\begin{array}{c}\text { Universidade } \\
\text { Federal de } \\
\text { São Carlos }\end{array}$ & $\begin{array}{c}592 \\
(8.1 \%)\end{array}$ & $\begin{array}{l}\text { Comisión } \\
\text { Nacional de } \\
\text { Energía } \\
\text { Atómica }\end{array}$ & $\begin{array}{l}216 \\
(3.0 \%)\end{array}$ & $\begin{array}{l}\text { Pontificia } \\
\text { Universidad } \\
\text { Católica de } \\
\text { Chile }\end{array}$ & $\begin{array}{l}88 \\
(1.2 \%)\end{array}$ & & \\
\hline $\begin{array}{l}\text { Universidade } \\
\text { Estadual } \\
\text { Paulista } \\
\text { 'Júlio de } \\
\text { Mesquita } \\
\text { Filho' }\end{array}$ & $\begin{array}{c}431 \\
(5.9 \%)\end{array}$ & $\begin{array}{l}\text { Consejo } \\
\text { Nacional de } \\
\text { Investigaciones } \\
\text { Científicas y } \\
\text { Técnicas }\end{array}$ & $\begin{array}{l}158 \\
(2.2 \%)\end{array}$ & $\begin{array}{l}\text { Universidad } \\
\text { de Santiago } \\
\text { de Chile }\end{array}$ & $\begin{array}{l}86 \\
(1.2 \%)\end{array}$ & & \\
\hline $\begin{array}{l}\text { Universidade } \\
\text { Federal do } \\
\text { Rio de } \\
\text { Janeiro }\end{array}$ & $\begin{array}{c}401 \\
(5.5 \%)\end{array}$ & $\begin{array}{l}\text { Universidad } \\
\text { Nacional de } \\
\text { Córdoba }\end{array}$ & $\begin{array}{l}153 \\
(2.1 \%)\end{array}$ & $\begin{array}{l}\text { Pontificia } \\
\text { Universidad } \\
\text { Católica de } \\
\text { Valparaíso }\end{array}$ & $\begin{array}{l}62 \\
(0.8 \%)\end{array}$ & & \\
\hline $\begin{array}{l}\text { Universidade } \\
\text { Federal do } \\
\text { Rio Grande } \\
\text { do Sul }\end{array}$ & $\begin{array}{c}322 \\
(4.4 \%)\end{array}$ & $\begin{array}{l}\text { Centro } \\
\text { Atómico } \\
\text { Bariloche }\end{array}$ & $\begin{array}{l}114 \\
(1.6 \%)\end{array}$ & $\begin{array}{l}\text { Universidad } \\
\text { Técnica } \\
\text { Federico } \\
\text { Santa María }\end{array}$ & $\begin{array}{l}54 \\
(0.7 \%)\end{array}$ & & \\
\hline $\begin{array}{l}\text { Universidade } \\
\text { Federal de } \\
\text { Minas } \\
\text { Gerais }\end{array}$ & $\begin{array}{c}294 \\
(4.0 \%)\end{array}$ & $\begin{array}{l}\text { Universidad } \\
\text { Nacional de } \\
\text { Mar del Plata }\end{array}$ & $\begin{array}{l}88 \\
(1.2 \%)\end{array}$ & $\begin{array}{l}\text { Universidad } \\
\text { Católica del } \\
\text { Norte }\end{array}$ & $\begin{array}{l}26 \\
(0.4 \%)\end{array}$ & & \\
\hline $\begin{array}{r}\text { Universidade } \\
\text { de Brasília }\end{array}$ & $\begin{array}{c}262 \\
(3.6 \%)\end{array}$ & $\begin{array}{l}\text { Instituto } \\
\text { Balseiro }\end{array}$ & $\begin{array}{c}68 \\
(0.9 \%)\end{array}$ & $\begin{array}{l}\text { Universidad } \\
\text { Austral Chile }\end{array}$ & $\begin{array}{c}20 \\
(0.3 \%)\end{array}$ & & \\
\hline $\begin{array}{l}\text { Universidade } \\
\text { Federal do } \\
\text { Ceará }\end{array}$ & $\begin{array}{c}201 \\
(2.8 \%)\end{array}$ & $\begin{array}{l}\text { Universidad } \\
\text { Nacional del } \\
\text { Sur }\end{array}$ & $\begin{array}{l}49 \\
(0.7 \%)\end{array}$ & $\begin{array}{l}\text { Universidad } \\
\text { Tecnológica } \\
\text { Metropolitana } \\
\text {-UTEM }\end{array}$ & $\begin{array}{l}16 \\
(0.2 \%)\end{array}$ & & \\
\hline $\begin{array}{l}\text { Universidade } \\
\text { Federal de } \\
\text { Pernambuco }\end{array}$ & $\begin{array}{c}175 \\
(2.4 \%)\end{array}$ & $\begin{array}{l}\text { Universidad } \\
\text { Nacional del } \\
\text { Litoral }\end{array}$ & $\begin{array}{l}48 \\
(0.7 \%)\end{array}$ & $\begin{array}{l}\text { Comisión } \\
\text { Chilena de } \\
\text { Energía } \\
\text { Nuclear- } \\
\text { CCHEN }\end{array}$ & $\begin{array}{c}13 \\
(0.2 \%)\end{array}$ & & \\
\hline
\end{tabular}

a To first half of 2006

Source: Analysis of Georgia Tech global nanotechnology publication dataset

Moreover, we note the weakness of industry involvement in nanotechnology research. For countries like Chile or Uruguay this is perhaps not surprising, given the emerging state of development in their industrial sectors. The weakness of industry involvement is most significant for Brazil (where conglomerates and internationally oriented companies have emerged in technology and natural resource sectors) and, to less extent, Argentina. Possible explanations for low industry involvement include the still early stage of nanotechnology development in Latin America, the weakness of domestic corporate 


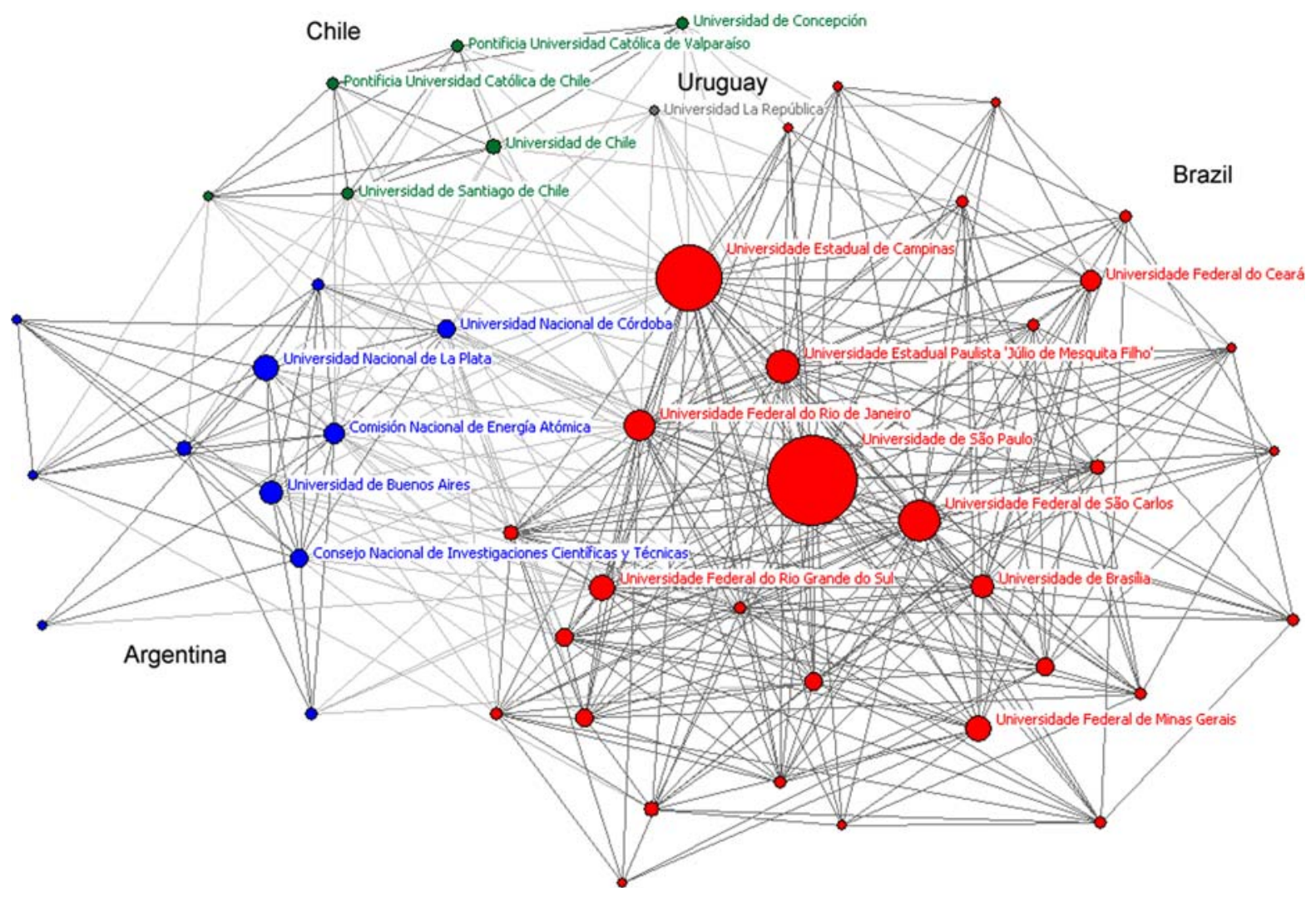

Fig. 3 Network of top nanotechnology institutions, selected countries. Notes: This network represents graphically the relationships between the top 50 research institutions in Argentina, Brazil, Chile, and Uruguay. Each node represents

$\mathrm{R} \& \mathrm{D}$, the dominance of foreign multi-national branches who draw on their own company rather than local universities for $R \& D$, a general lack of industry awareness of nanotechnology, and bureaucratic barriers faced by industry in working with universities. Whatever the causes, this finding foreshadows weaknesses not only in industry $R \& D$ but also in the absorptive capabilities of firms in Latin America to apply nanotechnology applications. In Brazil, given its efforts to develop aerospace, electronics, and other advanced technologies, as well as in the resource-intensive areas of all the countries (such as the prominent minerals, metals, and pulp and paper sectors in Chile) there may be unexploited opportunities for collaborative nanotechnology R\&D with industry in nanomaterials and other nanotechnology domains.

Related to this, we observe the concentration of nanotechnology research in a few disciplines and one institution and its size represent the country and the number of publications for the entire 1990-2006 (mid) period, respectively. The lines represent co-authorships

sectors in the four focal countries. ${ }^{29}$ Although this finding is not surprising when compared with results of previous research, we suggest that these countries might consider strategies that seek to better align public R\&D with industry and innovation priorities. At the same time, given the convergent scientific characteristics of nanotechnology, any approach should incorporate different disciplines (de la Vega

\footnotetext{
${ }^{29}$ Further research in this aspect should be made to draw more definitive conclusions. Previous research has shown that, for example, each one of the areas of physics, chemistry, and materials science, accounts for $50 \%$ or more of the total world publications in the period 1998-2001 (some publications are related to more than one area) (Glanzel et al. 2003). On the other hand, the proportion of publications in areas like Electrical \& Electronic Engineering seems to be relatively low even at the worldwide level. For example, Hullmann and Meyer (2003) found that, by 1999 only 3\% of worldwide nanotechnology publications were in the Electrical \& Electronic Engineering area.
} 
Table 6 Share of nanotechnology publications co-authored with other countries (percentages)

\begin{tabular}{llccc}
\hline Country & Brazil & Argentina & Chile & Uruguay \\
\hline Brazil & - & 6.5 & 11.6 & 14.8 \\
Argentina & 1.6 & - & 3.1 & 9.3 \\
Chile & 1.0 & 1.1 & - & 24.1 \\
Uruguay & 0.1 & 0.4 & 2.7 & - \\
USA & 9.4 & 12.0 & 7.3 & 11.1 \\
France & 5.3 & 4.9 & 8.7 & 5.6 \\
Spain & 2.2 & 13.5 & 13.5 & 11.1 \\
Germany & 4.3 & 5.0 & 4.4 & 0.0 \\
Italy & 2.3 & 5.0 & 1.5 & 5.6 \\
England & 1.9 & 2.0 & 2.3 & 1.9 \\
Japan & 2.2 & 1.1 & 0.4 & 1.9 \\
Canada & 1.6 & 1.0 & 2.1 & 0.0 \\
Cuba & 1.5 & 0.1 & 0.8 & 0.0 \\
Russia & 1.4 & 0.3 & 0.0 & 0.0 \\
Portugal & 1.2 & 0.6 & 0.8 & 0.0 \\
Belgium & 1.0 & 0.2 & 1.2 & 1.9 \\
Mexico & 0.4 & 1.8 & 2.3 & 0.0 \\
China & 0.8 & 0.5 & 1.0 & 1.9 \\
\hline Source & & & & \\
\hline
\end{tabular}

Source: Analysis of Georgia Tech global nanotechnology publication dataset. 1990-2006 (mid)

et al. 2007) as intended by, for example, by the Brazil multidisciplinary research programs. However, the data suggest that nanotechnology research may be not fully aligned with all key industry sectors. For example, there may be needs for additional efforts at nanotechnology interfaces in engineering and electronics in Brazil, and biology and agriculture in both Argentina and Uruguay. On the other hand, Chile is undertaking nanotechnology research in more diverse areas including biology, which is related to important sectors for the country such as forestry and fishing. We note that allying research with economic sectors and potential commercialization targets is not an insignificant task, and even in the leading international centers is not clear what (and how) opportunity area in nanotechnology should best be targeted (Zucker and Darby 2005). Still, there seem to be challenges here for Latin American countries in the mix of research areas: at present, research occurs where academic presence is strongest, but these areas may not always mesh with economic sector opportunities. At the same time, given the existing problems of research scale and resources, it may not be feasible for most Latin American countries to develop new research areas.

We found that "Southern" (or intra-MERCOSUR) collaboration levels are relatively low in these four countries. In spite of wide economic differences, we wonder if more emphasis on inter-regional collaborations to implement strategies that take advantage of shared research targets may be helpful. For Uruguay this is clearly an important component of its strategy. Considering it has few research institutions and relatively low industrial development, this strategy is central to at least minimally exploit nanotechnology without having a strong national S\&T system. For the other countries, intra-MERCOSUR collaboration also represents an opportunity. Brazil and Argentina are aware of this and have implemented a joint program, even though we were not able to find evidence of significant results from such collaborations.

Moreover, our data show relatively low government involvement in nanotechnology research publication, except for Argentina where there are several governmental labs that are actively involved in research. However, the role of government clearly may extend beyond this. Nanotechnology policies may give the role of broker to government agencies to enable knowledge transfer, sharing, and exchange between industry and academia. These agencies may also help in coordinating national R\&D efforts and promote broader participation and citizen input on the use of nanotechnology applications (Chiancone et al. 2007; Invernizzi 2007). Furthermore, they can design regulation schemes to ensure the development of nanotechnology according to social and environmental standards (Maynard 2006).

Finally, the lack of nanotechnology patenting activity has two possible explanations. The first is that these countries are in an early stage of nanotechnology development and only after some years they will be able to transform research knowledge to intellectual property that can be used for the commercialization of nanotechnology applications and nanotechnology-based products. The second explanation has more policy implications: not only may these countries be undertaking nanotechnology research that is not aligned to local industry priorities but there may also be insufficient incentives for researchers to collaborate with incumbent industries and to initiate their own start-up enterprises. If Latin 
Table 7 Freeman degree centrality based on nanotechnology publication co-authorships for the top 50 Latin American research institutions

\begin{tabular}{|c|c|c|}
\hline Institution & Degree & NrmDegree \\
\hline Universidade de São Paulo & 39 & 79.592 \\
\hline Universidade Estadual de Campinas & 39 & 79.592 \\
\hline Universidade Federal do Rio de Janeiro & 35 & 71.429 \\
\hline Universidade Federal de São Carlos & 33 & 67.347 \\
\hline Universidade Estadual Paulista 'Júlio de Mesquita Filho' & 30 & 61.224 \\
\hline Universidade Federal do Rio Grande do Sul & 27 & 55.102 \\
\hline Centro Brasileiro de Pesquisas Físicas & 26 & 53.061 \\
\hline Comisión Nacional de Energía Atómica & 22 & 44.898 \\
\hline Universidade de Brasília & 21 & 42.857 \\
\hline Universidade Federal do Paraná & 21 & 42.857 \\
\hline Associação Brasileira de Tecnologia Luz Síncroton & 21 & 42.857 \\
\hline Universidad Nacional de Córdoba & 20 & 40.816 \\
\hline Universidade Federal Fluminense & 19 & 38.776 \\
\hline Universidade Federal de Pernambuco & 18 & 36.735 \\
\hline Universidad Nacional de La Plata & 18 & 36.735 \\
\hline Pontifícia Universidade Católica do Rio de Janeiro & 18 & 36.735 \\
\hline Universidade Federal de Minas Gerais & 16 & 32.653 \\
\hline Universidad de Buenos Aires & 15 & 30.612 \\
\hline Consejo Nacional de Investigaciones Científicas y Técnicas & 15 & 30.612 \\
\hline Centro Atómico Bariloche & 15 & 30.612 \\
\hline
\end{tabular}

Notes: The analysis was made based on a symmetric matrix where the cells contain the number of co-authorships for the top 50 institutions in Argentina, Brazil, Chile, and Uruguay. Only the top 20 institutions are shown in the table. The Freeman degree centrality is defined as a measure of the degree of inequality or variance in the network as a percentage of that of a perfect star network of the same size. In a star network, all the actors but one have degree of one, and the "star" has a degree of the number of actors minus one (Freeman 1979). The normalized degree (NrmDegree column) is a measure relative to the size of the network, with a maximum of 100

American S\&T policymakers want to foster the development of nanotechnology and increase transfer to and take-up by key industry sectors, they may need to encourage research and incentives that can lead to the commercialization of new technologies in national and international markets. For this, it may be necessary to increase industry-academy collaborations, intellectual property protection, and enterprise support-all pending tasks for Latin American countries (Kraul 2003; Fernández and Schatzmann 2007; Foladori and Fuentes 2007).

\section{Concluding comments}

We have seen that Latin American countries, each one at its own scale, are implementing policies and programs to develop nanotechnology. However, almost all scientific research is concentrated in few countries and patenting is infrequent. Among the group comprising Argentina, Brazil, Chile, and Uruguay (the focus of this article), Brazil is clearly the leader in nanotechnology research, followed by Argentina. Chile is increasingly involving more institutions in nanotechnology research and looking for regional and international collaborations, while Uruguay concentrates almost all nanotechnology research in one institution. The assessment of data about nanotechnology publications suggests that Brazil is pursuing a strategy based on national targets, whereas Uruguay's strategy is based more on regional collaborations. On the other hand, Argentina and Chile rely more on national and international collaborations, respectively. Nanotechnology research in these four countries is concentrated in core disciplines of physics, 
chemistry, and materials science. This may not facilitate the development and use of nanotechnology in other key economic sectors for these countries (e.g. agriculture). The available patent data does not suggest any significant orientation to the commercialization of nanotechnology in these countries. In sum, the assessment of potential strategies that these and other Latin American countries may pursue suggests that they may wish to focus additional attention to various forms of research collaboration in nanotechnology, but they also need to reconcile this with challenges of ensuring relevance for national development, commercialization, and societal impact.

Acknowledgments This research was undertaken in association with the Center for Nanotechnology in Society at Arizona State University (CNS-ASU) sponsored by the National Science Foundation (Award No. 0531194). The findings and observations contained in this article are those of the authors and do not necessarily reflect the views of the National Science Foundation.

\section{References}

Almeida C (2005) Brazil and Argentina launch joint nanotech centre. Available via http://www.scidev.net/news/index.cfm? fuseaction=readnews\&itemid=2537. Accessed 29 Nov 2007

Andrini L, Figueroa SJA (2007) El impulso gubernamental a las nanociencias y nanotecnologías en Argentina. Available via http://estudiosdeldesarrollo.net/relans/documentos/ Argentina.pdf. Accessed 17 Dec 2007

Antunes A (Coordinator) (2004) Prospecção em Nanotecnologia: desenvolvimento tecnológico nos países-chave. Centro de Gestão e Estudios Estratégicos

Applebaum RP, Gereffi G, Parker R, Ong R (2006) From cheap labor to high-tech leadership: will China's investment in nanotechnology pay off? In: Society for the advancement of socio-economics, annual conference, June 2006

Bennett I, Sarewitz D (2006) Too little, too late? Research policies on the societal implications of nanotechnology in the United States. Sci Cult 15(4):309-325. doi:10.1080/ 09505430601022635

Besley J, Kramer V, Priest S (2008) Expert opinion on nanotechnology: risks, benefits, and regulation. J Nanopart Res 10(4):549-558. doi:10.1007/s11051-007-9323-6

Chiancone A, Chimuris R, Garrido Luzardo L (2007) La nanotecnología en el Uruguay. Available via http://est udiosdeldesarrollo.net/relans/documentos/URUGUAY. pdf. Accessed 17 Dec 2007

Cobb MD, Macoubrie J (2004) Public perceptions about nanotechnology: risks, benefits and trust. J Nanopart Res 6(4):395-405. doi:10.1007/s11051-004-3394-4

Correia A, Pérez M, Sáenz JJ, Serena PA (2007) Nanotechnology applications: a driving force for R\&D investment.
Phys Status Solidi 204(6):1611-1622. doi:10.1002/ pssa.200775364

de la Vega I, Suárez M, Blanco F, Troconis A, Aponte G (2007) Las tecnologías nanoscópicas en los centros y las periferias. El caso de los nanomateriales en Venezuela. Available via http://estudiosdeldesarrollo.net/relans/ documentos/VENEZUELA.pdf. Accessed 12 Dec 2007

Diario LaU (2005) Nanotecnología en el Mercosur. Available via http://www.conicet.gov.ar/NOTICIAS/ACTUALIDAD/ 2005/septiembre/035.php. Accessed 29 Nov 2007

Durán N, De Azevedo MMM (2002) Rede de pesquisa em nanobiotecnologia. Available via http://www.comciencia. $\mathrm{br} /$ reportagens/nanotecnologia/nano20.htm. Accessed 12 Nov 2007

European Commission (2005) Some figures about nanotechnology R\&D in Europe and beyond. DG Research, Brussels

Fernández N, Schatzmann F (2007) Nanotecnología: las empresas argentinas están en carrera. Available via http://www.ieco.clarin.com/notas/2007/10/14/01518214. html. Accessed 12 Dec 2007

Fogelberg H, Sanden BA (2008) Understanding reflexive systems of innovation: an analysis of Swedish nanotechnology discourse and organization. Technol Anal Strateg Manag 20(1):65-81. doi:10.1080/09537320701726593

Foladori G (2006) Nanotechnology in Latin America at the crossroads. Nanotechnol Law Bus J 3(2):205-216

Foladori G, Fuentes V (2007) Nanotechnology in Chile: towards a knowledge economy? Available via http:// estudiosdeldesarrollo.net/relans/documentos/clile-ing.pdf. Accessed 12 Dec 2007

Foladori G, Zayago E (2007) México se incorpora a la nueva revolución industrial de las nanotecnologías. Available via http://estudiosdeldesarrollo.net/relans/documentos/ Tracking-nano-in-MEXesp.pdf. Accessed 12 Dec 2007

Freeman LC (1979) Centrality in social networks conceptual clarification. Soc Netw 1(3):215-239. doi:10.1016/03788733(78)90021-7

Gaillard J (1992) Use of publication lists to study scientific production and strategies of scientists in developing countries. Scientometrics 23(1):57-73. doi:10.1007/ BF02020914

Glanzel W, Meyer M, Du Plessis M, Thijs B, Magerman T, Schlemmer B et al (2003) Nanotechnology, analysis of an emerging domain of scientific and technological endeavor. O\&O Statistieken, Leuven

Goncalves da Silva C (2003) O Programa Nacional de Nanotecnologia e o Centro Nacional de Referencia em Nanotecnologia. Available via http://www.lnls.br/info/ programaNano_a.pdf. Accessed 12 Dec 2007

Heinze T, Bauer G (2007) Characterizing creative scientists in nano S\&T: productivity, multidisciplinarity, and network brokerage in a longitudinal perspective. Scientometrics 70(3):811-830. doi:10.1007/s11192-007-0313-3

Heinze T, Shapira P, Rogers J, Senker J (2008) Research creativity. An exploration of pathbreaking science. Res Policy (forthcoming)

Hullmann A, Meyer M (2003) Publications and patents in nanotechnology. An overview of previous studies and the state of the art. Scientometrics 58(3):507-527. doi: 10.1023/B:SCIE.0000006877.45467.a7 
Invernizzi N (2007) Los científicos brasileños legitiman las nanotecnologías. Available via http://estudiosdeldesar rollo.net/relans/documentos/Noela-Visiones-esp.pdf. Accessed 12 Dec 2007

Invernizzi N, Foladori G (2005) Nanotechnology \& the developing world: will nanotechnology overcome poverty or widen disparities? Nanotechnol Law Bus J 2(3):1-10

Ishizu S, Sekiya M, Ishibashi KI, Negami Y, Ata M (2008) Toward the responsible innovation with nanotechnology in Japan: our scope. J Nanopart Res 10(2):229-254. doi: 10.1007/s11051-007-9306-7

Kostoff RN, Stump JA, Johnson D, Murday JS, Lau CGY, Tolles WM (2006) The structure and infrastructure of the global nanotechnology literature. J Nanopart Res 8(3-4): 301-321. doi:10.1007/s11051-005-9035-8

Kostoff RN, Koytcheff RG, Lau CGY (2007) Global nanotechnology research literature overview. Technol Forecast Soc Chang 74:1733-1747. doi:10.1016/j.techfore.2007.04.004

Kraul C (2003) For researchers in Mexico, apathy has been the smotherer of invention. Los Angeles Times, 4 December 2003

Lux Research (2007) The nanotechnology report, 5th edn. Lux Research Inc, New York

Malsch I (2004) Nanotechnology in Mexico. Available via http://www.merlinq.nl/index.php?option=com_content\&task =view\&id=297\&Itemid=74. Accessed 7 Mar 2008

Malsch I (2008a) Nanotechnology in Argentina. NanoforumE ULA, University of Twente, Netherlands. Available via http://www.mesaplus.utwente.nl/nanoforumeula/. Accessed 7 Mar 2008

Malsch I (2008b) Nanotechnology in Brazil. NanoforumEULA, University of Twente, Netherlands. Available via http://www.mesaplus.utwente.nl/nanoforumeula/. Accessed 20 Aug 2008

Martins PR, Dominguez Dulley R, Premebida A, Braga R (2007) Actividades relacionadas con las nanotecnologías en Brasil. Available via http://estudiosdeldesarrollo.net/ relans/documentos/Brasil.pdf. Accessed 12 Dec 2007

Maynard AD (2006) Nanotechnology: assessing the risks. Nano Today 1(2):22-33. doi:10.1016/S1748-0132(06) 70045-7

Nanoforum EULA (2007) Fact finding mission, Mexico. NanoforumEULA, University of Twente, Netherlands. Available via http://www.mesaplus.utwente.nl/nanoforum eula/. Accessed 20 Aug 2008

Niosi J, Reid SE (2007) Biotechnology and nanotechnology: science-based enabling technologies as windows of opportunity for LDCs? World Dev 35(3):426-438. doi: 10.1016/j.worlddev.2006.11.004

NSET (2004) The national nanotechnology initiative: strategic plan. Subcommittee on Nanoscale Science, Engineering and Technology, Committee on Technology, National Science and Technology Council, Executive Office of the President, Washington, DC

NSET (2005) Nanotechnology: societal implications-maximizing benefits for humanity. Report of the national nanotechnology initiative workshop, December 2-3, 2003. Subcommittee on Nanoscale Science, Engineering and Technology, Committee on Technology, National Science and Technology Council, Executive Office of the President, Washington, DC

NSET (2007) The national nanotechnology initiative: research and development leading to a revolution in technology and industry. Supplement to the President's 2008 budget. Subcommittee on Nanoscale Science, Engineering and Technology, Committee on Technology, National Science and Technology Council, Executive Office of the President, Washington, DC

Observatorio Cubano de Ciencia y Tecnologia (CCyT) (2002) Elementos Iniciales para el Analisis sobre la Nanotecnologia en Cuba. Ministerio de Ciencia, Tecnologia y Medioambiente, La Habana. Available via http://www. occyt.cu/varios/informenano.pdf. Accessed 22 Aug 2008

Porter AL, Youtie J, Shapira P, Schoeneck D (2008) Refining search terms for nanotechnology. J Nanopart Res 10(5):715-728. doi:10.1007/s11051-007-9266-y

RAE (2004) Nanoscience and nanotechnologies: opportunities and uncertainties. Royal Society and Royal Academy of Engineering, London

Roco MC (2003) Broader societal issues of nanotechnology. J Nanopart Res 5(3/4):181-189. doi:10.1023/A:102554 8512438

Roco MC (2005) International perspective on government nanotechnology funding in 2005. J Nanopart Res 7(6): 707-712. doi:10.1007/s11051-005-3141-5

Sametband R (2005) Ten-year nanotechnology plan proposed in Argentina. Available via http://www.scidev.net/con tent/news/eng/ten-year-nanotechnology-plan-proposedinargentina.cfm. Accessed 29 Nov 2007

Sarewitz D, Guston D (2004) Real-time assessment of nanotechnology: theory, practice, prospects. Conference on nanotechnology in science, economy, and society. Marburg, Germany, January 13-15, 2004. Available via http://cgi-host.uni-marburg.de/ nano-mr/downloads/s4/ sarewitz_paper_draft.pdf. Accessed 28 Mar 2008

Shapira P, Wang J (2008) From lab to market: strategies and issues in the commercialization of nanotechnology in China. Paper presented at association of Asian studies annual meeting, April 2008, Atlanta

Universia (2007) Estrechos vínculos en nanotecnología entre la Universidad de Santiago y centros internacionales de investigación. Available via http://www.universia.cl/port ada/actualidad/noticia_actualidad.jsp?noticia=119585. Accessed 29 Nov 2007

Vargas M (2004) Costa Rica opens region's first lab for nanotechnology. Available via http://www.scidev.net/ News/index.cfm?fuseaction=readNews\&itemid=1602\&lan guage $=1$. Accessed 7 Mar 2008

Zaitchik A (2007) Russia pours billions in oil profits into nanotech race. Wired. Available via http://www.wired. com/science/discoveries/news/2007/11/russian_nano. Accessed 25 Mar 2008

Zucker LG, Darby MR (2005) Socio-economic impact of nanoscale science: initial results and nanobank. National Bureau of Economic Research, Cambridge 